\title{
The Evolution of Plant Harvesting at The Dawn of Agriculture: Perspectives from Sickle Gloss Texture Analyses
}

\author{
Juan Ibáñez ( $\square$ ibanezjj@imf.csic.es ) \\ Spanish National Research Council \\ Patricia Anderson \\ French National Centre for Scientific Research \\ Amaia Arranz-Otaegui \\ French National Centre for Scientific Research \\ Jesús González-Urquijo \\ University of Cantabria \\ Anne Jörgensen-Lindahl \\ University of Copenhagen \\ Niccolò Mazzucco \\ Spanish National Research Council \\ Fiona Pichon \\ French National Centre for Scientific Research \\ Tobias Richter \\ University of Copenhagen
}

\section{Research Article}

Keywords: Archaeobotanical and genetic analysis, archaeobotanical record, plant harvesting, farming harvesting systems

Posted Date: January 4th, 2021

DOI: https://doi.org/10.21203/rs.3.rs-136472/v1

License: (c) (1) This work is licensed under a Creative Commons Attribution 4.0 International License. Read Full License 


\section{Abstract}

Archaeobotanical and genetic analysis of modern plant materials are drawing a complex scenario for the origins of cereal agriculture in the Levant. This paper presents an improved method for the study of early farming harvesting systems based on the texture analysis of gloss observed on sickle blades. We identify different harvesting activities (unripe/semi-ripe/ripe cereal reaping and reed and grass cutting) and evaluate their evolution during the time when plant cultivation activities started and domesticated crops appeared in the Levant $(12,800$ to $7000 \mathrm{cal} B C)$. The state of maturity of cereals when harvested shifted through time from unripe, to semi-ripe and finally to ripe. Most of these changes in harvesting techniques are explained by the modification of crops during the transition to agriculture. The shift of plant harvesting strategies was neither chronologically linear nor geographically homogeneous. Fully mature cereal harvesting starts to be dominant around $8500 \mathrm{cal}$ BC in Southern Levant and one millennium later in Northern Levant, which fits with the appearance of domestic varieties in the archaeobotanical record. The evolution of plant harvesting better fits with the gradualist model of explanation of cereal agriculture than with the punctuated one.

\section{Introduction}

Wheat and barley were first cultivated and domesticated in the Levant ${ }^{12}$. However when and where wild cereal cultivation and the exploitation of domestic varieties took place, which are crucial questions for understanding why and how hunter-gatherers became farmers, are a matter of vivid debate, opposing a progressive (protracted) model with an abrupt (core area) one 3456789 . Archaeobotanical data suggest that cereal domestication was the result of a series of events occurring at different places over thousands of years, during which wild wheat persisted in cultivated fields, with the process occurring more or less rapidly in different areas of southwest Asia ${ }^{10}$. Genomic analysis is showing the enormous complexity of the evolutionary history of the cereal domestication process, indicating genetic ancestry from numerous geographic regions and diverse wild genepools 11121314 1516 .

The analysis of sickle elements through use-wear analysis can offer a complementary source of information to archaeobotanical and genetic studies for disentangling this complex scenario ${ }^{17}{ }^{18}$. Sickle blades were crucial in the process of cereal domestication, as reaping with lithic tools allowed the preferential selection of mutant seeds with a solid rachis that most probably led to domestication ${ }^{19}$. Sickle blades are present in the Natufian sites and become more common in Pre-Pottery Neolithic sites, thus from ca. 13,000 to $7000 \mathrm{cal} \mathrm{BC}$, during the whole process of transition towards agriculture ${ }^{20}$. Plant (and cereal) cutting generates polish on the tool edge that, after some hours of use, can be observed macroscopically as a sheen that is called sickle gloss. The standard method of use-wear analysis relies on the microscopic observation and the visual comparison and matching of use-wear on experimental and archaeological tools ${ }^{21}{ }^{22}$. Using this method, a tendency to observe flatter and more abraded gloss in the later phases has been attested ${ }^{17} 18$. However, this qualitative use-wear analysis is insufficient to discriminate between tools used to cut different types of plants. During the last decade, a new quantitative method based on texture analysis of 3D use-wear polished surfaces, using confocal microscopy 2324 , is offering unprecedented precision and greater objectivity in the identification of the plants that were cut with lithic tools 2526 .

Our methodology (see extended description in Methods and Supplementary information) is based on the quantitative analysis of gloss texture on experimental tools used for cutting five plant categories. These included three types of cereals: 1) morphologically domestic (Triticum monoccocum, T. aestivum, T. diccocum and T. spelta), 2) morphologically wild but cultivated (T. boeoticum thaoudar) and 3) wild cereal species growing in natural stands (T.boeoticum, T. dicoccoides and Hordeum spontaneum), plus 4) reeds (Phragmites communis) and 5) another grass (Ampelodesmos mauritanica). The three categories of cereals were harvested at the point of maturity when it was possible to maximize the yield. This resulted in harvesting in an unripe state for spontaneously growing wild cereals, in a semi-ripe state for cultivated wild cereals and in a ripe state for domestic cereals. Gloss on experimental tools used in these five plant-cutting activities were scanned using confocal microscopy and 3D surfaces were obtained from these readings. These surfaces were measured using 25178 ISO parameters of texture analysis. Discriminant function analysis was used to obtain predictive algorithms (based on Bayes' theorem) for the classification of archaeological tools in one of the five experimental categories. To test the discriminant capacity of the method, one half of the 3D surfaces were classified against the other half, obtaining a good rate of correct grouping. This method was used to analyze 215 sickle elements from nineteen archaeological sites/periods in Northern and Southern Levant dating from ca. 12,800 to 7000 cal BC (Natufian to Late PPNB 
periods) (Fig. 1). These sites and time span cover the period and regions where cereal cultivation and domestication took place during the transition from hunter-gatherer to farming societies.

\section{Methods}

(For a more detailed description see Supplementary information)

Plant cutting generates use-polish on the tool edge that -after some hours of use- can be observed macroscopically as a sheen that is called sickle gloss. Experiments of harvesting wild cereal growing in natural stands, cultivated wild cereals, domestic cereals, reeds and grass were carried out. Between six and ten areas with gloss (650x500 $\mu \mathrm{m}$ each) were scanned with a Sensofar Plu Neox confocal microscope. The 3D surfaces were sampled, extracting areas of $200 \times 200 \mu \mathrm{m}$, which were processed and later measured with the Mountain 7 software, from Digital Surf. Several parameters of texture analysis defined in ISO 25178 were selected on the basis of their discriminant capacity for the five experimental categories. Quadratic discriminant function analysis was used to build a predictive model for group membership, based on the Bayes' theorem. The discriminant algorithms obtained from the texture analysis of experimental tools were used for the analysis of glossed tools recovered in archaeological sites.

The discriminant function analysis consistently groups the surfaces of use-wear polish resulting from cutting the three cereal types (domestic, wild cultivated and wild in natural stands), reeds and other grasses. Significant mean differences (Wilks' Lambda) were observed for all the predictor parameters and for discriminant functions, with $73 \%$ of the 3D surfaces correctly classified. Using the threshold of $45 \%$ of correct classification of samples for considering each experimental tool as correctly classified, all the experimental tools can be considered as correctly grouped. To test the real predictive capacity of the method, we blindly classified half of the samples against the other half. Eighteen experimental tools were correctly classified, while two can be considered as indeterminate, in which the threshold of $45 \%$ of the samples is not reached for any of the five categories.

The archaeological tools were classified in one of the five categories of plant cutting tools when more than $50 \%$ of the 3D surfaces were classified in one of the groups, otherwise, they were classified as indeterminate (Table 1). The classificatory threshold was raised in the archaeological tools (50\%) with respect to the experimental ones (45\%) in order to reduce the rate of potential errors. For ensembles of tools, we considered the proportion of 3D surfaces classified in each of the five plant cutting groups (Figs. 2 and 3). The index of the degree of maturity of harvested cereals per level/site (Fig. 4) was calculated considering exclusively the results attributed to cereal harvesting in the three stages of maturity. The proportion of unripe harvesting was multiplied by three, unripe harvesting by two and ripe harvesting by one and the addition was calculated. Thus, 300 would be the index of a site with exclusive unripe cutting and 100 in another one with exclusive ripe cutting.

Gloss texture analysis finds significant differences between the tools used for cutting the five plant categories in terms of roughness, isotropy, wavelength, complexity, depth and density of furrows and slope of surface points (Table 2). The capacity of gloss texture analysis to separate the five plant-cutting activities is explained by the different mechanical characteristics of cereals, reeds and grass. Phragmites stems are 5-15 mm wide and rigid, cereal stems are 1.5-2.5 $\mathrm{mm}$ wide and more flexible, while Ampelodesmos leaves are 3-9 mm wide, very supple but tenacious. The degree of humidity in the stems/leaves is higher in reeds as they grow in swampy areas, medium for the while evergreen Ampelodesmos grass and lower for cereals when they are cut in the late Spring or Summer. The capability to discriminate the three types of cereal-cutting tools is probably due to different degrees of humidity present in the stems when reaped. When the aim of cereal cultivation is maximizing the yield, cereals are harvested in a state of maturity that is as advanced as possible. Morphologically domesticated cereals are usually reaped when they are ripe and the grains are fully mature. In contrast, wild cereal stands are commonly harvested before the plant reaches maturation, that is green or semi-green, because once fully mature, the spikelets start to disarticulate, leading to grain-loss ${ }^{48} 17$. Interestingly, our method shows clear differences between the experimental tools used to harvest wild cereals from natural stands in Syria and Israel and those used to cut wild cereals cultivated in Jalès (France). Texture analysis places the use-wear created when harvesting cultivated wild cereals in an intermediate position, between wild spontaneous and domestic cereal cutting tools. To explain this discrimination, we suggest several possible explanations. 1) Synchronous planting and harvesting may lead to more homogeneous ripening even after very few generations of cultivated cereals ${ }^{49}$. In the experimental carried out in Jalès, wild cereals were sown very densely on rich soil, and the plots developed thick stands that matured uniformly ${ }^{48}$. 2) These wild cereal cultivation experiments demonstrated that the most productive yield is obtained when crops are in a semi-ripe stage, which lasts 
few days. During this short period the seeds are more developed than in an unripe or green stage. Harvesting is thus more productive, yet at the same time, grain-loss is avoided, as the plants are not mature enough for the ear to disarticulate during harvesting ${ }^{48} 18$. Besides, cultivated fields of wild cereals can be more thoroughly surveyed than natural stands, because they are located near villages, and thus they can be more easily harvested in a more advanced moment of maturity. 3) In experimentally grown natural stands, cereals flourished together with a mix of other plants that compete with them, including perennial grasses, while in cultivated fields the dominance of cereals is expected (by clearance of the field or weeding). Thus, when harvesting spontaneously growing wild cereal stands, the diversity of plants harvested is greater than in cultivated fields, and include green perennial grasses, which could affect gloss texture, increase roughness, complexity, density of furrows and slope of surface points, while decreasing isotropy and wavelength (see Table 2).

Our method enables a high confidence in the classification of cereal harvesting tools in three states of maturity: unripe, the state in which wild cereals in natural stands were harvested; semi-ripe, the condition in which experimental wild cultivated cereals were cut at Jalès; and ripe, the state in which domestic cereals were reaped. However, for archaeological tools, it is not possible to automatically equate the degree of humidity of cereal when harvested with a specific step in the process towards agriculture (i.e. unripe cutting=harvesting wild cereals in natural stands). Ripe stems of wild cereals could be harvested for feeding the livestock or for technical activities such as basketry or for roofing houses. Similarly, domestic cereals can be cut in a semi-ripe state for making freekeh, a kind of roasted snack where the taste of the unripe grain is sought. Environmental humidity/dryness can influence the degree of moisture of cereals when harvested. Another issue is the possibility that one sickle could have been used for cutting different types of plants. In this case, texture analyses would result in an indeterminate classification of the tool or in the classification of the tool in the group of dominant use. These factors have to be considered when interpreting the archaeological data. However, when information of gloss texture analysis is considered in conjunction with the archaeobotanical information, it is possible is to evaluate how plant harvesting systems changed with the development of plant cultivation and domestication. In this work, we interpret the evidence by assuming that people in the past were trying to achieve the highest yield, which was most probably the goal during the origins of agriculture as this is a prerequisite for explaining the process of genetic selection leading to domestication. The evolution towards riper cereal harvesting from 12,800 to 7,000 cal BC both in Northern and Southern Levant strongly suggests that these changes in harvesting strategies were related to crop management shifts that took place during the transition to agriculture.

\section{Data Availability}

The datasets generated during and/or analysed during the current study are available in the Digital CSIC repository, http://hdl.handle.net/10261/225522

\section{Results}

The results of the analysis are listed according to the classification of individual tools (Table 1) or the proportion of 3D surfaces classified in each of the five plant working groups in the archaeological contexts (see Fig. 2 for Southern Levant and Fig. 3 for Northern Levant). An index of the degree of maturity of harvested cereals (Fig. 4) was calculated for the sites/levels in the Northern and Southern Levant (see Supplementary information). The tendency to harvest riper cereals through time can be observed in both regions. However, some differences appear, as from the Early PPNB harvesting in the South is consistently riper than in the North.

Table 1. Results of the sickle gloss texture analysis for archaeological tools. Numbers represent individual sickle blades. 


\begin{tabular}{|c|c|c|c|c|c|c|c|c|c|c|}
\hline SITE & PERIOD & CHRONOLOGY & REGION & $\begin{array}{l}\text { Ripe } \\
\text { cereal }\end{array}$ & $\begin{array}{l}\text { Semi- } \\
\text { ripe } \\
\text { cereal }\end{array}$ & $\begin{array}{l}\text { Unripe } \\
\text { cereal }\end{array}$ & Reeds & Grass & Indeterminate & Total \\
\hline $\begin{array}{l}\text { Hayonim } \\
\text { Terrace }\end{array}$ & Natufian & $\begin{array}{l}11,700- \\
11,200\end{array}$ & S. Levant & & & 4 & 4 & 0 & 10 & 18 \\
\hline $\begin{array}{l}\text { Shubayqa } \\
1\end{array}$ & Natufian & $\begin{array}{l}12,400- \\
11,100 \mathrm{BC}\end{array}$ & S. Levant & & 1 & & 1 & 1 & 1 & 4 \\
\hline $\begin{array}{l}\text { Shubayqa } \\
6\end{array}$ & Natufian & $\begin{array}{l}10,300-9800 \\
\mathrm{BC}\end{array}$ & S. Levant & & & & & & 2 & 2 \\
\hline $\begin{array}{l}\text { Shubayqa } \\
6\end{array}$ & EPPNA & $\begin{array}{l}9900-9200 \\
\text { BC }\end{array}$ & S. Levant & & 2 & & & & 2 & 4 \\
\hline Kharaysin & PPNA & $\begin{array}{l}9100-8700 \\
\text { BC }\end{array}$ & S. Levant & & 1 & & & & 2 & 3 \\
\hline $\begin{array}{l}\text { Tell } \\
\text { Qarassa } \\
\text { North }\end{array}$ & EPPNB & $\begin{array}{l}8500-8200 \\
\text { BC }\end{array}$ & S. Levant & 30 & 5 & 3 & 1 & & 10 & 49 \\
\hline Kharaysin & EPPNB & $\begin{array}{l}8400-8250 \\
\text { BC }\end{array}$ & S. Levant & 6 & & 1 & & & & 7 \\
\hline Kharaysin & MPPNB & $\begin{array}{l}8000-7600 \\
\text { BC }\end{array}$ & S. Levant & 7 & 1 & & & & & 8 \\
\hline $\begin{array}{l}\text { Nahal } \\
\text { Hemar }\end{array}$ & MPPNB & $\begin{array}{l}7700-71001 \\
\mathrm{BC}\end{array}$ & S. Levant & 1 & & & & & & 1 \\
\hline Ba'ja & LPPNB & $\begin{array}{l}7500-6900 I \\
B C\end{array}$ & S. Levant & 1 & 1 & & & & & 2 \\
\hline $\begin{array}{l}\text { Abu } \\
\text { Hureyra }\end{array}$ & Natufian & $\begin{array}{l}11,200- \\
10,700 \mathrm{BC}\end{array}$ & $\begin{array}{l}\text { M. } \\
\text { Euphrates }\end{array}$ & & 1 & & & & 3 & 4 \\
\hline $\begin{array}{l}\text { Tell } \\
\text { Mureybet }\end{array}$ & Natufian & $\begin{array}{l}10,400- \\
10,000 \mathrm{BC}\end{array}$ & $\begin{array}{l}\text { M. } \\
\text { Euphrates }\end{array}$ & & 2 & & & & 1 & 3 \\
\hline $\begin{array}{l}\text { Tell } \\
\text { Mureybet }\end{array}$ & PPNA & $\begin{array}{l}9600-8700 \\
\text { BC }\end{array}$ & $\begin{array}{l}\text { M. } \\
\text { Euphrates }\end{array}$ & 3 & 2 & 3 & 1 & & 4 & 13 \\
\hline $\begin{array}{l}\text { Jer el } \\
\text { Ahmar }\end{array}$ & LPPNA & $\begin{array}{l}8800-8600 \\
\text { BC }\end{array}$ & $\begin{array}{l}\text { M. } \\
\text { Euphrates }\end{array}$ & 7 & 2 & 2 & & & 4 & 15 \\
\hline $\begin{array}{l}\text { Tell } \\
\text { Mureybet }\end{array}$ & EPPNB & $\begin{array}{l}8600-8300 \\
\text { BC }\end{array}$ & $\begin{array}{l}\text { M. } \\
\text { Euphrates }\end{array}$ & 3 & 3 & 1 & & & 3 & 10 \\
\hline $\begin{array}{l}\text { Dja'de el } \\
\text { Mughara }\end{array}$ & EPPNB & $\begin{array}{l}8540-8290 \\
\text { BC }\end{array}$ & $\begin{array}{l}\text { M. } \\
\text { Euphrates }\end{array}$ & 7 & 16 & 0 & & 4 & 21 & 48 \\
\hline $\begin{array}{l}\text { Abu } \\
\text { Hureyra }\end{array}$ & MPPNB & $\begin{array}{l}7700-7400 \\
\text { BC }\end{array}$ & $\begin{array}{l}\text { M. } \\
\text { Euphrates }\end{array}$ & 1 & 4 & & & & & 5 \\
\hline $\begin{array}{l}\text { Tell } \\
\text { Halula }\end{array}$ & MPPNB & $\begin{array}{l}7700-7400 \\
\text { BC }\end{array}$ & $\begin{array}{l}\text { M. } \\
\text { Euphrates }\end{array}$ & 5 & & & & & 4 & 9 \\
\hline $\begin{array}{l}\text { Tell } \\
\text { Halula }\end{array}$ & LPPNB & $\begin{array}{l}7300-7000 \\
B C\end{array}$ & $\begin{array}{l}\text { M. } \\
\text { Euphrates }\end{array}$ & 5 & 4 & & & & 1 & 10 \\
\hline
\end{tabular}

\section{Evolution of plant harvesting techniques in the Southern Levant}

In the Southern Levant, the sickles from the Natufian site of Hayonim Terrace analyzed for this study indicate both harvesting of unripe cereals, as well as reed cutting during the 12th millennium cal BC. Unripe cereal harvesting stands out among the tools used for cereal cutting. The archaeobotanical analysis identified wild barley (Hordeum spontaneum) among the archaeobotanical macro-remain assemblage ${ }^{27}$, while phytolith analysis showed the existence of remains of seed husks from mostly wild wheat and 
abundant wild barley, as well as phytoliths from stems of cereals/grasses, reeds and rushes ${ }^{28}$. The combination of archaeobotanical and use-wear lines of evidence suggests that wild uncultivated cereals were harvested at the site. The gloss texture analysis from Shubayqa 1 and 6 (Natufian) indicates a variety of plant-cutting activities, including the cutting of semi-ripe cereals, reeds and other grasses. The initial analysis of the Shubayqa 1 archaeobotanical assemblage suggests that cereal grasses were rarely exploited by its inhabitants, whereas Cyperaceae tubers dominated the assemblage ${ }^{29}$. This corresponds to the rarity of sickle flint tools in the lithic assemblage, although there are many ground stone artefacts at the site ${ }^{30}$. Wild cereals and club-rush tubers were used to produce flat bread-like products ${ }^{31}$. In these Natufian sites, gloss texture analysis shows a variety of plant-cutting activities (cereals, reeds and other grass), while the importance of unripe harvesting suggests the exploitation of wild cereals in natural stands in Hayonim Terrace.

The data from Shubayqa 6 and Kharaysin 1 (PPNA) indicate cutting of semi-ripe cereals. This could potentially be interpreted as evidence for harvesting cultivated wild cereals, which fits the archaeobotanical information indicating wild cereal cultivation during this period in southern Levant ${ }^{32}$. Nevertheless, few tools from these sites were analyzed and the archaeobotanical study of both sites has not been completed yet so this conclusion has to be considered as preliminary. Like Shubayqa 1, sickle blades are rare in the Shubayqa 6 lithic assemblage, although there are many ground stone artefacts at the site. Further analysis of additional sickles from these and other Natufian and PPNA sites in the southern Levant are necessary to interpret the evidence obtained.

Dominant ripe cereal-harvesting appears for the first time in the Early PPNB levels of Tell Qarassa North (TQN) around cal 8500 cal BC. The cereal assemblage from TQN comprises wild and domesticated-type species of emmer wheat (T. dicoccoides/dicoccum), one- and two-grained einkorn wheat (T. boeoticum/monococcum/urartu), and barley (Hordeum spontaneum/vulgare).

Domesticated-type scars were identified on the emmer, einkorn, and barley chaff at a frequency higher than expected in wild cereal species (21.1-41.2\%). Based on these results it can be concluded that by $8,700-8,200$ cal BC there are positive signs that barley, emmer and einkorn were being cultivated and partially domesticated at TQN ${ }^{9}$. In the contemporaneous levels of Tell Aswad, emmer and barley were exploited and the latter also shows high proportions of domestic type spikelets (30\%) ${ }^{33} 34$. Gloss texture analysis finds higher proportions of ripe harvesting than would correspond to a context where fully domesticated cereals only reach $30-40 \%$ (see also below). Ripe cereal harvesting continues to dominate in the slightly later Early PPNB levels of Kharaysin $(8,400-8,100 \mathrm{cal}$ BC), in the Middle PPNB levels of the same site (8,000-7,700 BC) and one sickle from Nahal Hemar, while in the Late PPNB levels at Ba'ja ripe cereal cutting decreases and semi-ripe cutting stands out slightly. Thus, ripe harvesting starts to become dominant in Southern Levant from the Early PPNB, which fits well with the presence of domestic varieties of cereals from that period observed in archaeobotanical assemblages ${ }^{33}$. Unripe cereal cutting is marginal in the period in which ripe cereal harvesting dominates (mid 9th to mid-8th millennium BC), though it is still present in the EPPNB at Tell Qarassa North and Kharaysin.

Reed cutting is observed in the older periods/sites as in Hayonim Terrace, Shubayqa 1 and 6 and Kharaysin PPNA. However, from the Early PPNB onward reed cutting is very marginal. Reed cutting, an activity likely related to the making of baskets, matting or for roofing houses, is more easily detected in contexts in which cereal harvesting was not very prevalent. However, when cereal harvesting became dominant among plant-cutting activities, from the EPPNB onwards, other plant-cutting tools likely decreased proportionally in comparison to cereal-cutting tools.

\section{Evolution of plant harvesting techniques in the Northern Levant}

In the Northern Levant, the sickle blades from the Late Natufian at Abu Hureyra and Mureybet show use-wear patterns that correspond to experimental sickles used to cut both semi-ripe and unripe cereals. The presence of sickles showing evidence for cutting unripe cereals is not surprising considering that if wild cereals were harvested, cutting them green would be most advantageous to obtain the maximum yield. However, it is interesting to highlight the presence of sickle blades that, based on texture parameters, coincide with those that were used to harvest cultivated wild cereals in our experiments. Whether Natufian groups were cultivating wild cereal stands has been a matter of discussion since the $1950 \mathrm{~s}^{35} 3637$. To date, there is no clear empirical archaeobotanical data that supports this possibility ${ }^{38}{ }^{39}$. In fact, the proportion of cereals among other plant resources in the archaeobotanical record of Abu Hureyra 1 and Mureybet I is small ${ }^{36} 40$. Taken together, our results could suggest that Natufian groups at these sites were exploiting both wild cereal stands and, perhaps, managed fields, where cereals were growing in 
denser stands and could therefore be optimized for harvesting in a semi-ripe stage. Further archaeobotanical and gloss texture analysis is needed to verify this hypothesis.

From the end of the 10th to the end of the 9th millennium cal BC, ripe, semi-ripe and unripe harvesting are present at Mureybet III (PPNA), Jerf el Ahmar (Late PPNA), Mureybet IVA (Early PPNB) and Dja'de el Mughara (Early PPNB). In all these contexts, archaeobotanical evidence suggests the large-scale cultivation of morphologically wild cereals 4142434434 . The prevalence of semi-ripe harvesting in these sites/levels (dominant in Mureybet III and IV and in Dja'de) fits well with the cultivation of wild cereals 44 . The identification of unripe cereal cutting, especially in the PPNA levels of Mureybet III and Jerf el Ahmar, suggests that spontaneous wild cereals were also exploited. Sickle gloss texture analysis also indicates that ripe harvesting was common in these contexts even though domestic cereals were not present. Unripe cereal cutting tends to diminish through time and it is marginal or inexistent in the PPNB contexts/sites (Mureybet IVA, Dja'de, Abu Hureyra and Halula). The appearance of relevant proportions of ripe harvesting before domestic varieties were dominant is also observed in the Early PPNB levels of Tell Qarassa North, in the southern Levant. This could suggest that before the appearance of domesticated cereals, prior to the fixation of the tough nature of rachis, cultivated wild cereals were evolving traits that progressively allowed for a more mature harvesting of the crops. This scenario would have been possible because persistent planting and harvesting together favored plants to grow in synchronization ${ }^{45}$ and reduced the proportion of immature grains harvested ${ }^{46}$. Wild cereals that could be harvested in a drier state because they reached ripeness more homogeneously would match gloss texture of our experimental tools used for harvesting domestic cereals.

In the Middle PPNB occupations of Abu Hureyra the harvesting of semi-ripe cereals is still more common than of fully mature ones. In this site/level domestic varieties such as free-threshing Triticum sp appear, accompanied by grains of H.spontaneum/distichum and T.dicoccoides/dicoccum ${ }^{37}$. In the Middle and Late PPNB levels of Tell Halula (from 7600 to 7000 cal BC) sickle elements mainly fall into the group of ripe harvesting, though the cutting of semi-ripe cereals is also relevant. Two-rowed barley (Hordeum distichum), naked wheat (Triticum aestivum/durum) and emmer (Triticum dicoccum) were the main cereals exploited at the site. The presence of $T$. aestivum/durum demonstrates the presence of domesticated cereals, though wild cereals were also exploited 47. This is the period when sickle gloss texture shows, for the first time in the area, the dominance of ripe harvesting over unripe and semi-ripe ones.

Table 2. Comparative texture characteristics of gloss on experimental tools used for cutting the five categories of plants.

\begin{tabular}{|llll|}
\hline & High & Medium & Low \\
\hline Roughness & Reeds, grass & Wild spontaneous & Wild cultivated, domestic \\
\hline Isotropy & Domestic, wild cultivated & Wild spontaneous & Reeds, grass \\
\hline Wavelength & Wild cultivated & Domestic, wild spontaneous & Reeds, grass \\
\hline Complexity & Wild spontaneous, grass & Domestic, wild cultivated & Reeds \\
\hline Depth of furrows & Reeds & Grass, wild cultivated & Domestic, wild cultivated \\
\hline Density of furrows & Domestic, grass & wild cultivated, wild spontaneous & Reeds \\
\hline Slope of surface points & Reeds & Wild spontaneous, grass & Domestic, wild cultivated \\
\hline
\end{tabular}

\section{Discussion}

Overall, gloss texture analysis shows shifting strategies in plant harvesting during the transition to agriculture in the Levant. This information, together with the archaeobotanical data, offers a more detailed view of how plants were exploited in such a crucial period. In the older sites/levels (Natufian and PPNA) a greater variety of plants were harvested, including cereals, reeds and other grasses, while from the PPNA in Northern Levant and the Early PPNB in Southern Levant, when large-scale cereal exploitation is detected ${ }^{43}$, cereal harvesting becomes dominant among plant-cutting activities. The proportion of glossed tools classified as indeterminate (Table 1 ) tends to diminish through time (54,8\% of the tools in the Natufian period, $34.3 \%$ in the PPNA, $29,8 \%$ in the Early PPNB, $17.4 \%$ in the MPPNB and $8.3 \%$ in the Late PPNB). This would indicate that plant-cutting tools in the older periods were 
more often used for reaping different types of plants compared to the later periods, when tools were more often used for harvesting one type of plant, mainly cereals.

Our data also show the changes in the state of cereals when harvested from unripe, to semi-ripe and finally to ripe. The state of maturity of harvested cereals depends on multiple factors. Thus, it cannot be automatically related to the harvesting of cereals with shattering or non-shattering spikes (see Methods). However, the evolution towards riper harvesting from 12,000 to $7000 \mathrm{BC}$ strongly suggests that the main factor explaining our results was the modification of crops in the transition to agriculture. The evolution of plant harvesting better fits with the gradualist model of explanation of cereal agriculture ${ }^{4}$ than a punctuated model ${ }^{3}$ implying unchanged unripe harvesting before $8500 \mathrm{BC}$ and sudden predominance of ripe reaping after that date.

In this process of shift, taking together both gloss texture analyses and the archaeobotanical data available, several phases can be distinguished. The dominance of unripe harvesting in Hayonim Terrace $\left(12^{\text {th }}\right.$ millennium BC) would indicate the exploitation of wild cereals in natural stands. The presence of semi-ripe and unripe-cereal cutting in the Middle Euphrates in the $11^{\text {th }}$ millennium $\mathrm{BC}$ suggests that, besides harvesting natural stands, human groups could have already started exploiting incipiently managed cereal fields that allowed for the harvesting of plants in a semi-ripe state. The unripe, semi-ripe and ripe cereal harvesting in the PPNA and Early PPNB in the Middle Euphrates would indicate the simultaneous harvesting of cultivated wild cereals that were at different stages in the domestication process, accompanied by the marginal exploitation of cereals in natural stands. This means that roughly contemporaneous cereal fields were reaped at different stages of maturity. Probably, besides the harvesting of wild cereals in natural stands (unripe cutting), fields with cereals that were cultivated in different conditions or were at disparate steps in the process of domestication were cultivated and harvested. This variability could be explained by the coexistence of different

cereal species or varieties. The dominance of ripe harvesting in Southern Levant from the EPPNB and in Northern Levant from the Middle PPNB onwards would correspond to the exploitation of domestic cereal varieties, which would have started in southern Levant around 8,500 BC, one millennium before the Middle Euphrates.

Despite the observed tendency to harvest riper cereals from 12,000 to $7000 \mathrm{BC}$ in the Levant, the process is uneven in time and space. In the Middle Euphrates, for example, the proportion of ripe cutting fluctuates from Mureybet II-III to Jerf el Ahmar, Dja'de III, Abu Hureyra 2 and Tell Halula. In Southern Levant, from the EPPNB, riper harvesting is observed compared to Northern Levant. Geographic and chronological fluctuations in the proportions of unripe, semi-ripe and ripe cereal harvesting show that the development of plant harvesting strategies was neither chronologically linear nor geographically homogeneous.

\section{Declarations}

\section{Acknowledgments}

We acknowledge all the archaeologists who excavated the sites from which the glossed tools analyzed in this paper have been recovered: Dr. J. Cauvin, Dr H. Gebel, Dr. D. Stordeur, Dr- M. Molist, Dr. E. Coqueugniot, Dr. F. Valla, Dr. A.M.T. Moore and Dr. O. BarYosef. The research has been funded by the Spanish Ministry of Science (PID2019-105767GB-I00), the Shelby White-Leon Levy Foundation (Publication of Tell Qarassa), the Palarq Foundation (Excavation of Kharaysin) and the Consejo Superior de Investigaciones Científicas (Proyectos Intramurales para Arqueología en el Exterior).

Author contributions statement: Designed research: JJI-E, PCA, JEG-U; Performed research: JJI-E; Analyzed data: JJI-E, NM, FP, AJL; Interpreted data: all authors; Wrote the paper: JJI-E, AA-O, PCA, JEG-U, NM, FP, TR

Additional Information: Competing Interest Statement: The authors declare no competing interests.

\section{References}

1. Harlan, J.R. The Living Fields: Our Agricultural Heritage. Cambridge Univ. Press, Cambridge, UK. (1995).

2. Zohary, D. \& Hopf, M. Domestication of Plants in the Old World, third ed. Clarendon Press, Oxford. (2000).

3. Abbo, Lev-Yadun, S. \& Gopher, A. Agricultural origins: centers and noncenters: a Near Eastern reappraisal. Crit. Rev. Plant Sci. 29, 317-328 (2010) 
4. Fuller, D.Q., Willcox, G. \& Allaby, R.G. Cultivation and domestication had multiple origins: arguments against the core area hypothesis for the origins of agriculture in the Near East. World Archaeol. 43, 628-652, (2011)

5. Fuller, D.Q., Asouti, E. \& Purugganan, M.D. Cultivation as slow evolutionary entanglement: comparative data on rate and sequence of domestication. Hist. Archaeobotany 21, 131-145. https://doi.org/10.1007/s00334-011-0329-8. (2012)

6. Fuller, D.Q., Willcox, G. \& Allaby, R.G. Early agricultural pathways: moving outside the "core area" hypothesis in Southwest Asia. Exp. Bot. 63, 617-633. https://doi.org/10.1093/jxb/err307. (2012)

7. Pankin, A. Altmüller, J. Becker, C. \& von Korff, M. Targeted resequencing reveals genomic signatures of barley domestication. New Phytologist. Special Issue: Featured papers on 'Plant proteases', 218-3, 1247-1259, https://doi.org/10.1111/nph.15077 (2018)

8. Abbo, S. \& Gopher, A. Plant domestication in the Neolithic Near East: The humans-plants liaison. Quaternary Science Reviews, 242,106412. (2020)

9. Arranz-Otaegui, A., Colledge, S., Zapata, L., Teira-Mayolini, L.C. \& Ibáñez, J.J. Regional diversity on the timing for the initial appearance of cereal cultivation and domestication in southwest Asia. Natl. Acad. Sci. U. S. A. 113 (49), 14001-14006. https://doi.org/10.1073/pnas.1612797113. (2016)

10. Tanno, K. \& Willcox, G. How fast was wild wheat domesticated? Science 311, 1886. (2006)

11. Kilian, B., Özkan, H., Walther, A., Kohl, J., Dagan, T., Salamini, F. \& Martin, W. Molecular diversity at 18 loci in 321 wild and 92 domesticate lines reveal no reduction of nucleotide diversity during Triticum monococcum (einkorn) domestication: Implications for the origin of agriculture. Mol Biol Evol 24:2657-2668. (2007)

12. Civáň, P., Ivaničová, Z. \& Brown, TA. Reticulated Origin of Domesticated Emmer Wheat Supports a Dynamic Model for the Emergence of Agriculture in the Fertile Crescent. PLOS ONE 8(11): e81955. https://doi.org/10.1371/journal.pone.0081955 (2013)

13. Poets, A.M. et al. Barley landraces are characterized by geographically heterogeneous genomic origins. Genome Bio/ 16,173 . https://doi.org/10.1186/s13059-015-0712-3 (2015)

14. Pankin, A. \& von Korff, M. Co-evolution of methods and thoughts in cereal domestication studies: a tale of barley (Hordeum vulgare). Current Opinion in Plant Biology, 36, Pages 15-21. https://doi.org/10.1016/j.pbi.2016.12.001 (2017)

15. Haas, M. Schreiber, M. \& Mascher, M. Domestication and crop evolution of wheat and barley: Genes, genomics, and future directions. Journal of Integrative Plant Biology, Volume 61, Issue 3, Special Issue: Barley and wheat biology, Pages 204-225. https://doi.org/10.1111/jipb.12737 (2019)

16. Oliveira, HR., Jacocks, L., Czajkowska, BI., Kennedy, SL. \& Brown TA. Multiregional origins of the domesticated tetraploid wheats. PLoS ONE 15(1): https://doi.org/ 10.1371/journal.pone.0227148 (2020)

17. Anderson, P.C. Experimental cultivation, harvest and threshing of wild cereals. Their Relevance for Interpreting the Use of Epipalaeolithic and Neolithic Artifacts in Prehistory of Agriculture. New Experimental and Ethnographic Approaches (ed. Anderson,P.C),. 118-139 (University of California, Los Angeles,1992).

18. Unger-Hamilton, R. Experiments in harvesting wild cereals and other plants in Préhistoire de l'agriculture: nouvelles approches expérimentales et ethnographiques (ed. Anderson, P.C.), 211-224 (Monographie du CRA, vol. 6. CNRS,1992)

19. Hillman, G. \& Davies, M.S. Domestication rates in wild wheats and barley under primitive cultivation. J. Linn. Soc. 39, 39-78. (1990)

20. Maeda, O. Lucas, L. Silva, F. Tanno, K. Fuller \& D.Q. Narrowing the harvest: Increasing sickle investment and the rise of domesticated cereal agriculture in the Fertile Crescent. Quaternary Science Reviews, Volume 145, 1, Pages $226-237$ (2016)

21. Plisson, H. Étude fonctionnelle d'outillages lithiques préhistoriques par l'analyse des micro-usures: recherche méthodologique et archéologique. Thèse de Doctorat. l'Université de Paris I, Paris. (1985)

22. van Gijn, A. The wear and tear of flint. Principles of functional analysis applied to Dutch neolithic assemblages. Analecta Praehistorica Leidensia, Leiden (1989)

23. Evans, A.A. \& Donahue, R.E. Laser scanning confocal microscopy: a potential technique for the study of lithic microwear. Archaeol. Sci. 35, 2223-2230 (2008) 
24. Ibáñez, J. J., Lazuen, T. \& González-Urquijo, J.E. Identifying experimental tool use through confocal microscopy. Journal of Archaeological Method and Theory 26(3): 1176-1215 (2019)

25. Ibáñez, J.J. González-Urquijo, J.E. Gibaja, J. Discriminating wild vs domestic cereal harvesting micropolish through laser confocal microscopy. Archaeol. Sci. 48, 96-103 (2014)

26. Ibáñez, J.J., Anderson, P.C., González-Urquijo, J.E \& Gibaja, J. Cereal cultivation and domestication as shown by microtexture analysis of sickle gloss through confocal microscopy. Archaeol. Sci. 73, 62-81 (2016)

27. Buxó, R. Quelques aspects des restes paléo-botaniques prélevés sur la Terrasse d'Hayonim (Haute Galilée) in Préhistoire de l'agriculture: nouvelles approches expérimentales et ethnographiques (ed. Anderson, P.C.), 225-229 (Monographie du CRA, vol. 6. CNRS,1992).

28. Rosen, A.M. Preliminary identification of silica skeletons from Near Eastern archaeological sites: an anatomical approach in Phytolith Systematics: Emerging Issues (eds Rapp Jr., G. \& Mulholland, S.C.), 129-148 (Plenum, New York, 1992).

29. Arranz-Otaegui, A. González Carretero, L. \& Richter, T. "Founder crops" v. wild plants: Assessing the plant-based diet of the last hunter-gatherers in southwest Asia. Quaternary Science Reviews, Volume 186, 263-283. (2018)

30. Pedersen, PN. Richter, T. Arranz-Otaegui, A. Preliminary Analysis of the Ground Stone from Shubayqa 1, Jordan, Journal of Lithic Studies, bind 3, nr. 3, s. 1-24. https://doi.org/10.2218/jls.v3i3.1647 (2016)

31. Arranz-Otaegui, A. González Carretero, L. Ramsey, M.N. Fuller \& D.Q. Richter, T. Archaeobotanical evidence reveals the origins of bread 14,400 years ago in northeastern Jordan. Natl. Acad. Sci. U. S. A. 31, 7925-7930.

https://doi.org/10.1073/pnas.1801071115 (2018)

32. Weiss, E. \& Kislev, M.E. Hartmann, A. Autonomous cultivation before domestication. Science 312, 1608-1610. (2006)

33. Tanno, K. \& Willcox, G. Distinguishing wild and domestic wheat and barley spikelets from early Holocene sites in the Near East. Veget Hist Archaeobot 21:107-115. (2012)

34. Douché, C. \& Willcox, G. New archaeobotanical data from the Early Neolithic sites of Dja'de el-Mughara and Tell Aswad (Syria): a comparison between the Northern and the Southern Levant. Paléorient, 44/2, 45-57. (2018)

35. Henry, O.D. From foraging to agriculture: the Levant at the end of the Ice Age. Philadelphia: University of Pennsylvania Press. (1989)

36. Hillman, G.C. Plant Food Economy at Abu Hureyra in Village on the Euphrates. From Foraging to Farming at Abu Hureyra (eds. Moore, A.M.T., Hillman, G.C. \& Legge, A.J.), 372-392 (Oxford University Press, New York, 2000).

37. Bar-Yosef, O. Climatic Fluctuations and Early Farming in West and East Asia. Current Anthropology, Volume 52, Supplement 4, S175. (2011)

38. Colledge, S. \& Conolly, J. Reassessing the evidence for the cultivation of wild crops during the Younger Dryas at Tell Abu Hureyra, Syria. Environmental Archaeology 15(2), 124-38. (2010)

39. Willcox, G. The beginnings of cereal cultivation and domestication in Southwest Asia in A companion to the archaeology of the ancient Near East (ed Potts, D.), 163-180, (Blackwell, 2012).

40. van Zeist., W. \& Bakker-Heeres, J.H. Archaeobotanical studies in the Levant 3. Late Palaeolithic Mureybet. Palaeohistoria 26: 171-199. (1984)

41. Colledge, S. Identifying predomestication cultivation using multivariate analysis in The Origins of Agriculture and Crop Domestication (eds. Damania, A.B., Valkoun, J., Willcox, G. \& Qualset, C.O.), 121-131, (ICARDA, Aleppo, 1998).

42. Willcox, G. Fornite, S. \& Herveux, L. Early Holocene cultivation before domestication in northern Syria. Veget Hist Archaeobot 17:313-325. (2008).

43. Willcox, G. \& Stordeur, D. Large-scale cereal processing before domestication during the tenth millennium BC cal. in northern Syria. Antiquity 86: 331, 99-114. (2012).

44. Pichon, F. Ibáñez-Estevez, J.J. Anderson, P.C. Douché, C. \& Coqueugniot, É. Harvesting cereals at Dja'de el-Mughara in the northern Levant: new results through microtexture analysis of Early PPNB sickle gloss ( $11^{\text {th }}$ millennium cal BP). JAS: Reports (accepted, in press).

45. Fuller, D.Q. Contrasting patterns in crop domestication and domestication rates: recent archaeobotanical insights from the Old World. Bot. 100, 903-924. (2007) 
46. Fuller, D.Q. \& Allaby, R. Seed dispersal and crop domestication: shattering, germination and seasonality R.in evolution under cultivation. Plant Rev. 38, 238-295. (2009)

47. Buxó, R. \& Rovira N. Tell Halula: arqueobotánica de los restos de semillas y frutos in Tell Halula: un poblado de los primeros agricultores en el valle del Éufrates, Siria. (ed. M. Molist), 359-389 (Memoria Científica - Tomo I y II. Ministerio de Educación, Cultura y Deporte. Secretaría General Técnica. Subdirección General de Documentación y Publicaciones. Madrid, 2013).

48. Willcox, G. Archaebotanical significance of growing Near Eastern progenitors of domestic plants at Jalès (France) in Préhistoire de l'agriculture: Nouvelles approches expérimentales et ethnographiques (ed Anderson,P.C.), 159-178, (Monographie du CRA N 6,. Editions du CNRS, 1992)

49. Harlan, J.R. Wild grass seed harvesting and implications for domestication in Préhistoire de l'agriculture: Nouvelles approches expérimentales et ethnographiques (ed Anderson, P.C.), 21-28, (Monographie du CRA № 6, Éditions du CNRS, 1992).

\section{Figures}

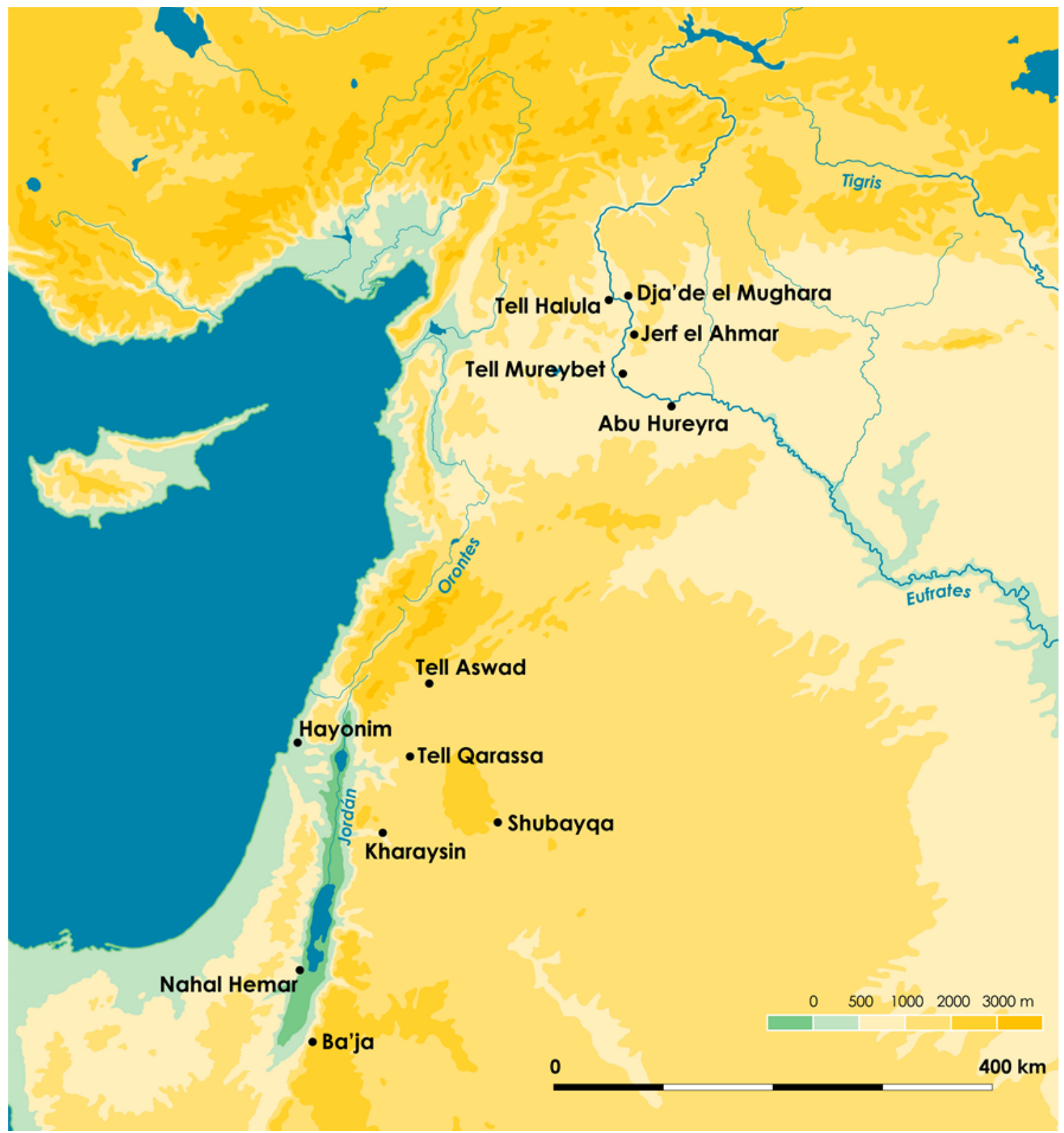

\section{Figure 1}


Map with the archaeological sites from which sickle blades have been analyzed. Note: The designations employed and the presentation of the material on this map do not imply the expression of any opinion whatsoever on the part of Research Square concerning the legal status of any country, territory, city or area or of its authorities, or concerning the delimitation of its frontiers or boundaries. This map has been provided by the authors.

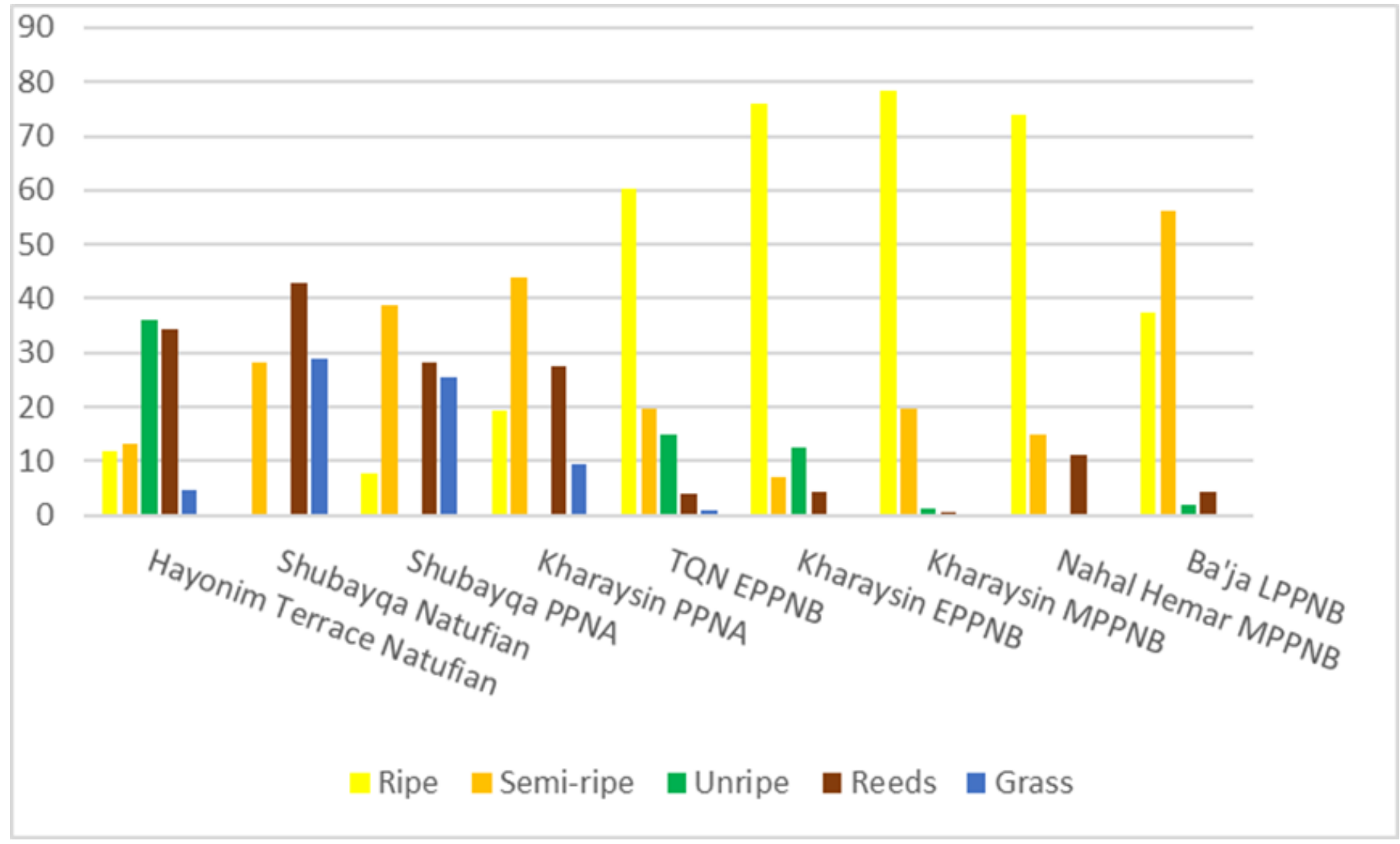

Figure 2

Classification of the 3D surfaces of gloss on the five categories of plant-cutting tools from archaeological sites in Southern Levant. 


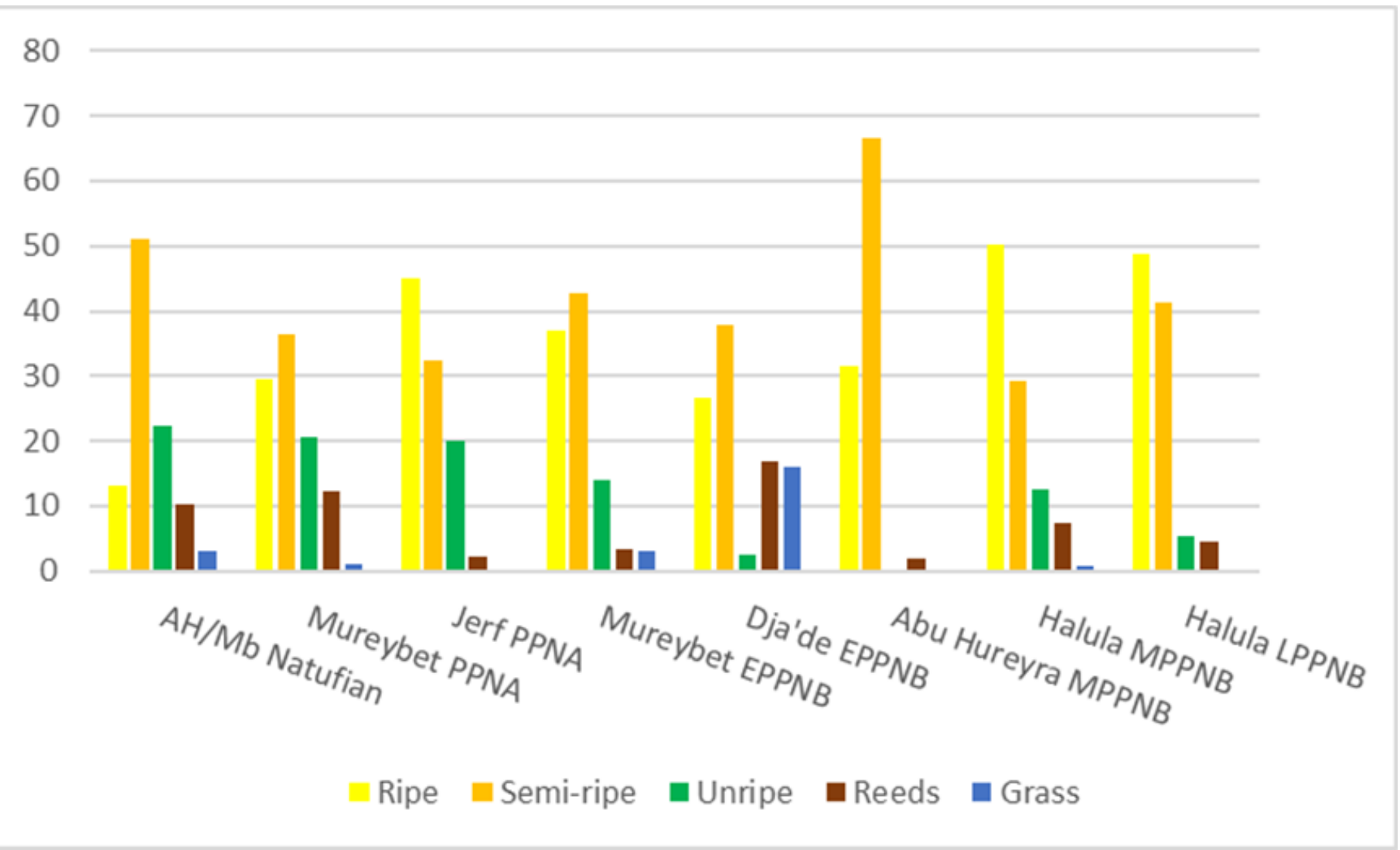

Figure 3

Classification of the 3D surfaces of gloss on the five categories of plant-cutting tools from sites in Northern Levant.

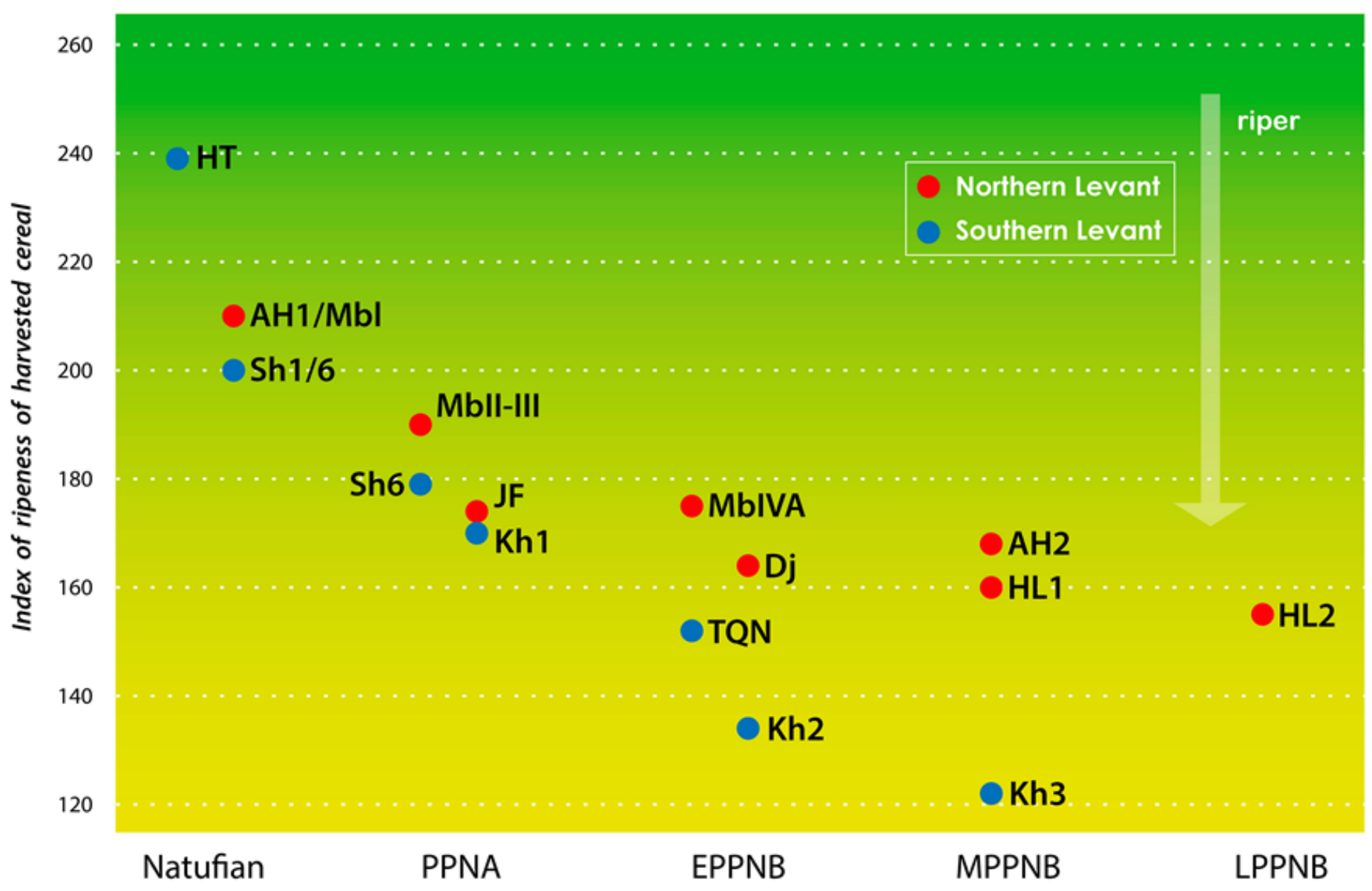


Figure 4

Evolution of the index of the degree of maturity of harvested cereals in Southern and Northern Levant. HT: Hayonim Terrace. AH1/Mbl: Abu Hureyra and Tell Mureybet (Natufian); Sh1/6: Shubayqa 1 and 6 (Natufian); Sh6: Shubayqa 6 (PPNA); JF: Jerf el Ahmar (PPNA); Kh1: Kharaysin (PPNA); MbIVA: Tell Mureybet (EPPNB); TQN: Tell Qarassa North (EPPNB); Dj: Dja'de el Mughara (EPPNB); Kh2: Kharaysin (EPPNB); HL1: Tell Halula (MPPNB); Kh3: Kharaysin (MPPNB); HL2: Tell Halula (LPPNB).

\section{Supplementary Files}

This is a list of supplementary files associated with this preprint. Click to download.

- Supplementaryinformation.docx 